\title{
DAPHNIOLA RADOMAN, 1973 (CAENOGASTROPODA: TRUNCATELLOIDEA) AT EAST AEGEAN ISLANDS
}

\author{
MAgdalena SZAROWSKA ${ }^{1}$, Sebastian HOFMAN ${ }^{2}$, ARTUR OSIKOWSKI ${ }^{2}$, ANDRZEJ FALNIOWSKI ${ }^{1}$
}

\begin{abstract}
${ }^{1}$ Department of Malacology, Institute of Zoology, Jagiellonian University, Gronostajowa 9, 30-387 Cracow, Poland (e-mail: andrzej.falniowski@uj.edu.pl)

${ }^{2}$ Department of Comparative Anatomy, Institute of Zoology, Jagiellonian University, Gronostajowa 9, 30-387 Cracow, Poland
\end{abstract}

\begin{abstract}
Shell habitus and COI mitochondrial gene sequences of one freshwater snail from Khios and three from Rhodes islands were analysed. Both methods confirmed assignment of these specimens to the genus Daphniola Radoman, 1973. Genetic distance between individuals from these two islands is surprisingly low, strongly suggesting that they belong to the same species, still undescribed. Comparison of COI sequences with other known species of this genus shows that the closest relative of the Khios and Rhodes populations is D. louisi Falniowski et Szarowska, 2000 from Attica. The results are discussed in the context of geological and climatic history of the Mediterranean.
\end{abstract}

\section{INTRODUCTION}

A number of freshwater valvatiform hydrobiid gastropods that occur in European habitats were recently reviewed by BODON et al. (2001). RADOMAN (1973) described a new genus Daphniola, with its new type species D. graeca Radoman, 1973, from Daphne Spring in Témbi Valley, northern Greece (Fig. 1). In his review of the Greek Hydrobiidae, SCHÜTT (1980) assigned the valavatiform hydrobiids, which had been reported from that territory, to Horatia Bourguignat, 1887 . He not only expanded the range of this genus far to the south without any justification (RADOMAN 1983), but also he included the species of Daphniola in Horatia unreasonably. Our molecular data did not confirm any closer relationship between Horatia and Daphniola (SZAROWSKA \& FALNIOWSKI 2014).

There are three species assigned to Daphniola currently. SCHÜTT (1980) synonymised Daphniola graeca with D. exigua (A. Schmidt, 1856). GITTENBERGER (1982) described a new species of Horatia (Horatia hadei Gittenberger, 1982), found $5 \mathrm{~km} \mathrm{SW}$ of Yíthion (Gythion), Peloponnese (Fig. 1), however, molecular and morphological data placed this species in the genus Daphniola (FALNIOWSKI \& SZAROWSKA 2011a). FALNIOWSKI \& SZAROWSKA (2000) described a new species of Daphniola (D. louisi Falniowski et Szarowska, 2000) from Kessariani Monastery, Athens (Fig. 1). Molecular data confirmed that D. exigua and $D$. graeca were the same species, different from D. louisi (FALNIOWSKI et al. 2007). Another species was described from the Parnassos Mountain within this genus (RADEA 2011). However, this species - Daphniola eptalophos Radea, 2011 - does not represent Daphniola (which is clearly visible in the figures and description of RADEA 2011). It is Graecoarganiella parnassiana Falniowski et Szarowska 2011 occurring at this locality (FALNIOWSKI \& SZAROWSKA 2011b). Daphniola was considered endemic for continental Greece (RADEA et al. 2013) up to now.

In this work we describe Daphniola individuals from two East Aegean islands. In June 2012 we found a single specimen of Daphniola at Khios Island, and three specimens at Rhodes Island. The material was too scarce for any morphological study, but we obtained cytochrome oxidase subunit I (COI) mtDNA partial sequences to confirm the genus-level assignment of those specimens, and to infer their phylogenetic relationships with the other, previously described continental representatives of Daphniola. 


\section{MATERIAL AND METHODS}

The snails were collected from two islands, situated in the eastern Aegean Sea (Fig. 1):

- Khios Island, a small spring (Fig. 2) near the road, 4 km E of Leptópodha, 38³4'23.6”N, 2559'12.3”E, $390 \mathrm{~m}$ a.s.l., together with Pseudamnicola and Bythinella, only a single specimen of Daphniola was found;

- Rhodes Island, a spring (Fig. 3) $5 \mathrm{~km}$ E of Sálakos, $36^{\circ} 17^{\prime} 0.4 .1^{\prime \prime} \mathrm{N}, 28^{\circ} 00^{\prime} 30.6^{\prime} \mathrm{E}, 210 \mathrm{~m}$ a.s.l.; together with Pseudamnicola, only three juvenile specimens of Daphniola were found.

Snails were washed twice in $80 \%$ ethanol and left to stand in it for around 12 hours. The $80 \%$ ethanol was then changed twice more within 24 hours and finally, after a few days, replaced with $96 \%$ ethanol, in which the samples were then stored at $-20^{\circ} \mathrm{C}$. The shells were photographed with a CANON EOS $50 \mathrm{D}$ digital camera mounted on a NIKON SMZ-18 microscope.
DNA was extracted from foot tissue. The tissue was hydrated in TE buffer $(3 \times 10 \mathrm{~min})$; then total genomic DNA was extracted with the SHERLOCK extracting kit (A\&A Biotechnology), and the final product was dissolved in $20 \mu \mathrm{l}$ TE pH 8.0 buffer. The PCR reaction was performed with the following primers: LCO1490 (5'-GGTCAACAAATCATAAAGATATTGG-3') (FOLMER et al. 1994) and COR722b (5'-TAAACTTCAGGGTGACCAAAAAATYA-3') (WILKE \& DAVIS 2000) to cytochrome oxidase subunit I (COI) mitochondrial gene.

The PCR conditions were as follows: initial denaturation step of $4 \mathrm{~min}$ at $94^{\circ} \mathrm{C}$, followed by 35 cycles of $1 \mathrm{~min}$ at $94^{\circ} \mathrm{C}, 1 \mathrm{~min}$ at $55^{\circ} \mathrm{C}, 2 \mathrm{~min}$ at $72^{\circ} \mathrm{C}$, and a final extension of $4 \mathrm{~min}$ at $72^{\circ} \mathrm{C}$. The total volume of each PCR reaction mixture was $50 \mu \mathrm{l}$. To check the quality of the PCR products, $10 \mu \mathrm{l}$ of the PCR product were run on a $1 \%$ agarose gel. The PCR products were purified using Clean-Up columns

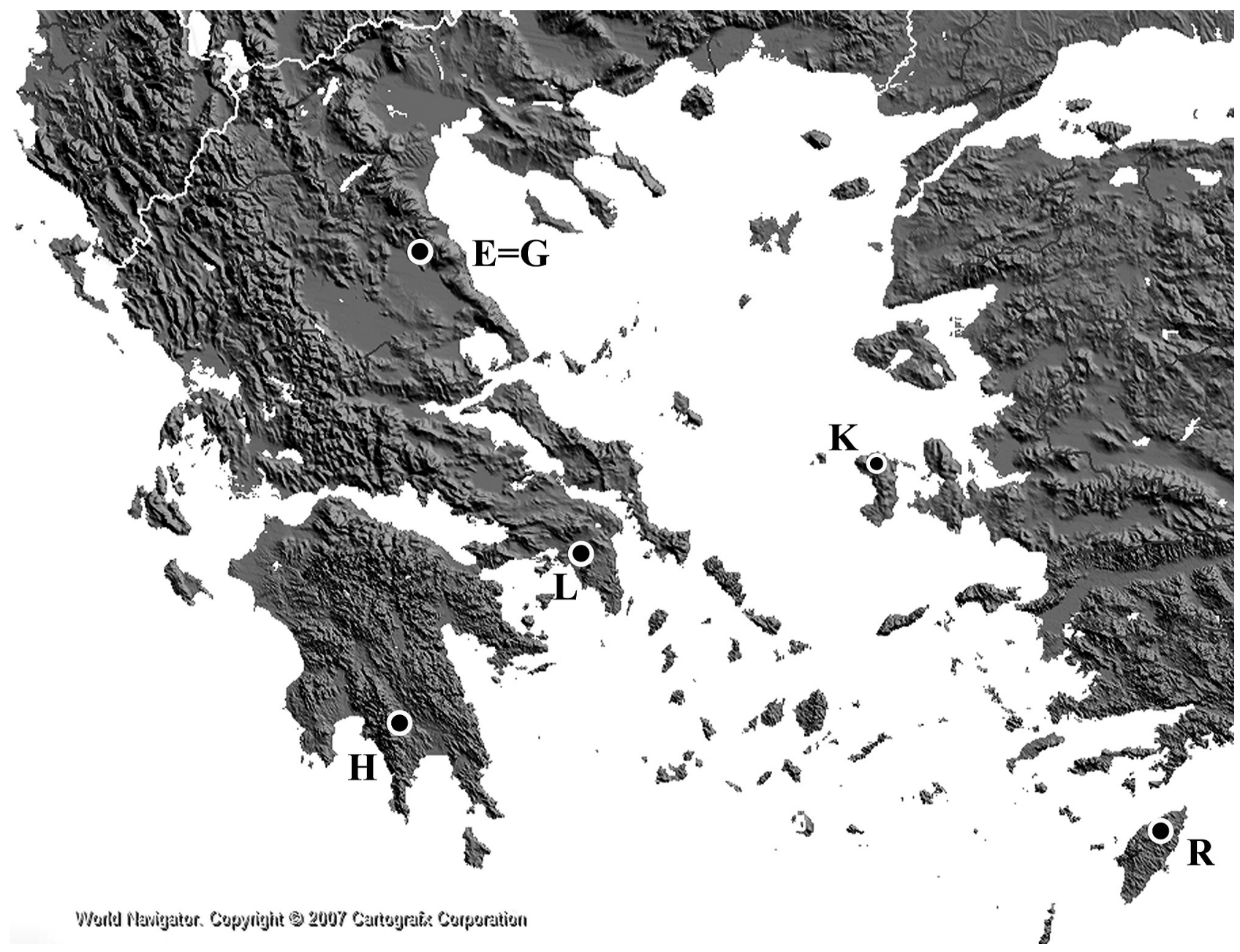

Fig. 1. Localities of populations of Daphniola used for molecular phylogeny: $E=G-D$. exigua, Aghia Paraskevi, Tembi Valley and D. graeca, Daphne Spring, Tembi Valley; H - D. hadei, S. Peloponnese, L - D. louisi, Kessariani, Attica, K - Khios Island, R - Rhodes Island. Figure made using Cartografx Professional Software 


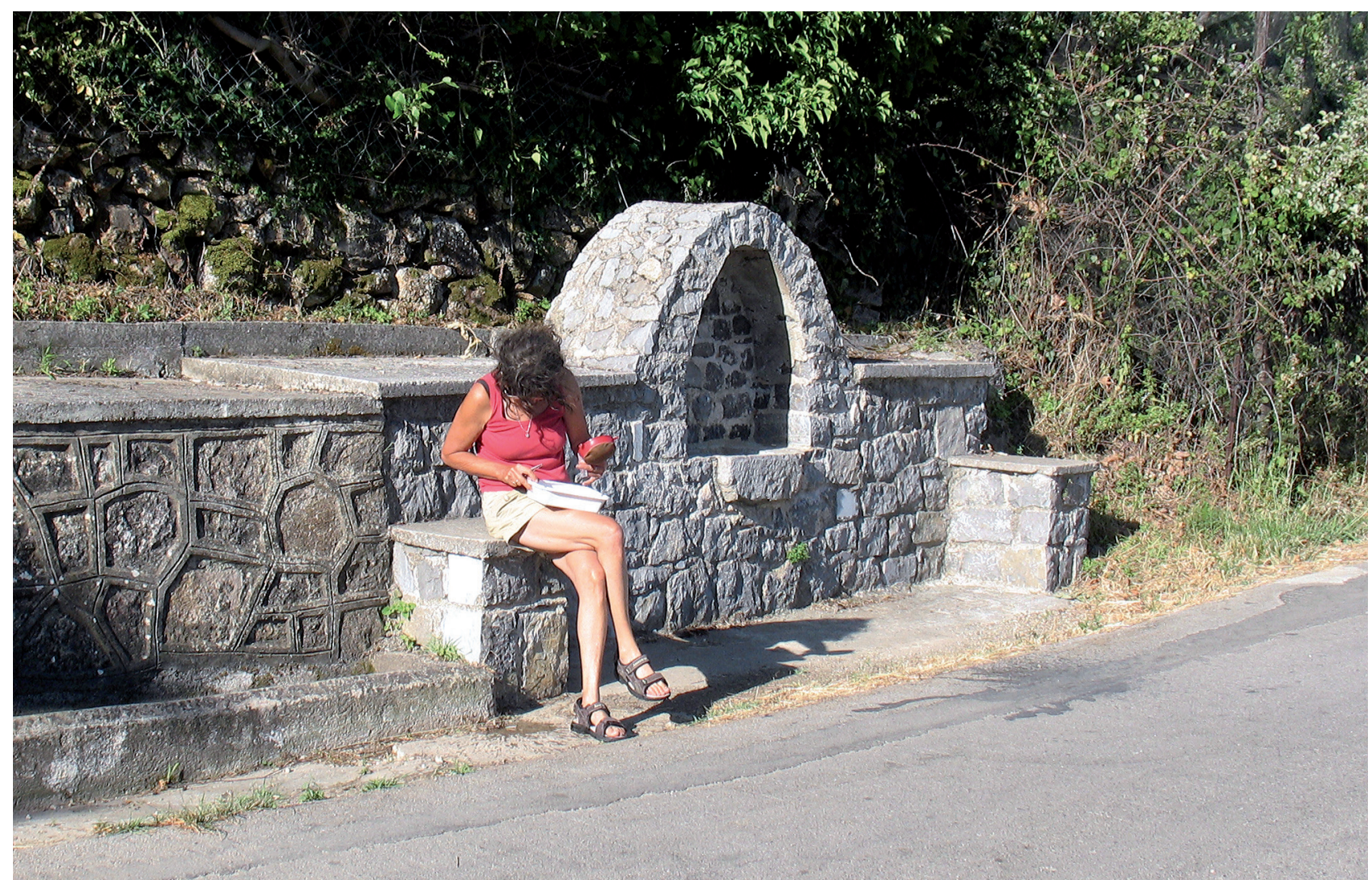

Fig. 2. Khios Island, a small spring $4 \mathrm{~km}$ E of Leptópodha

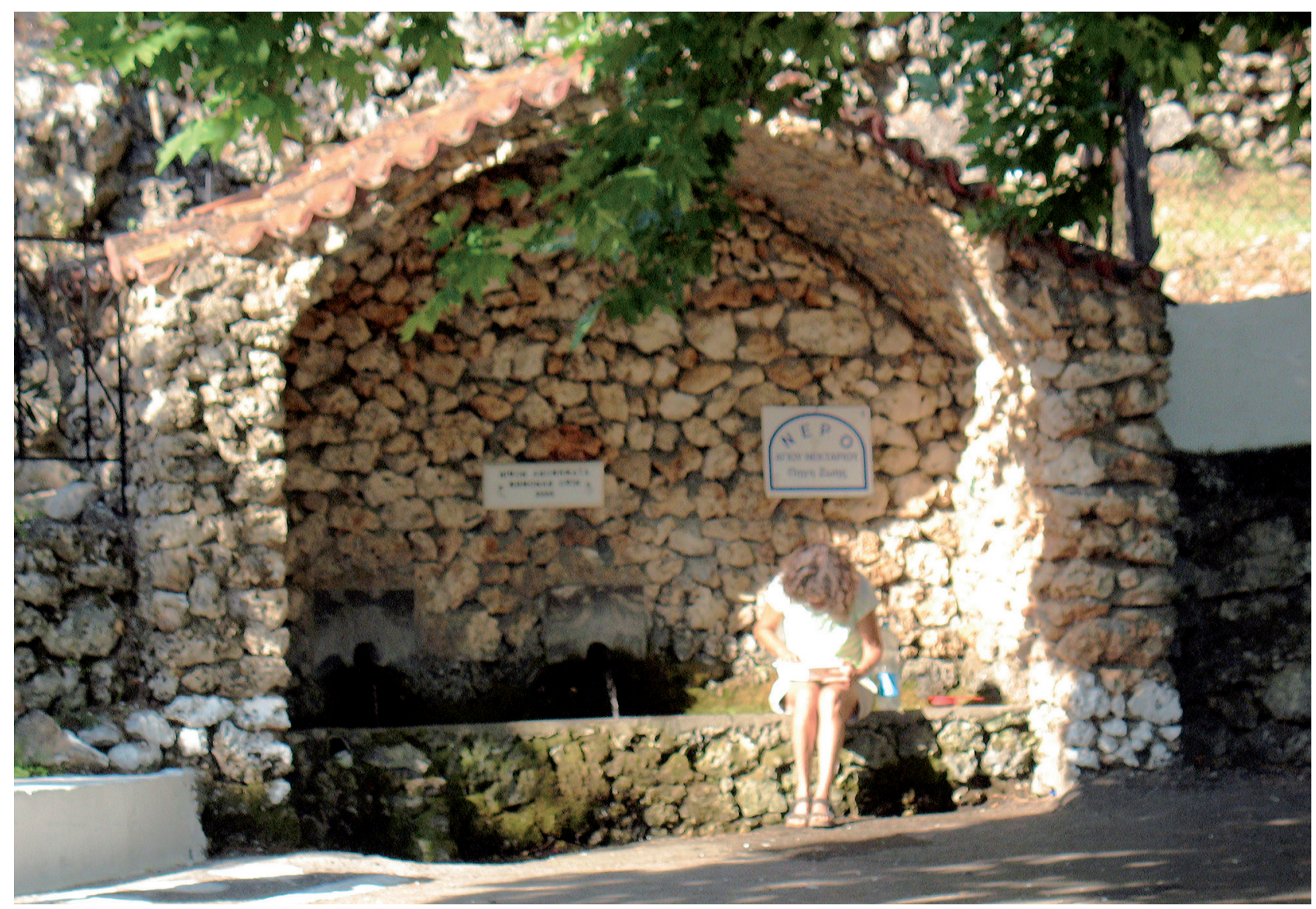

Fig. 3. Rhodes Island, a spring $5 \mathrm{~km}$ E of Sálakos 
(A\&A Biotechnology) and were then amplified in both directions (HILLIS et al. 1996) with the primers described above, using BigDye Terminator v3.1 (Applied Biosystems) according to the manufacturer's protocol. The sequencing reaction products were purified using ExTerminator Columns (A\&A Biotechnology); DNA sequences then underwent electrophoresis on an ABI Prism sequencer.

The sequences KM887914 and KM887915 were deposited in GenBank for Daphniola from Khios Island and Rhodes Island, respectively. They were aligned manually in Bioedit 7.1.3.0 (HALL 1999), together with the sequences from GenBank, representing the other three species of Daphniola: D. louisi (EF070618; FALNIOWSKI \& SZAROWSKA 2000), D. hadei (JF16473; FALNIOWSKI \& SZAROWSKA 2011a), D. exigua and D. graeca (EU047767, EU047763; FALNIOWSKI et al. 2007), and Grossuana codreanui (Grossu, 1946) (EF061919; SZAROWSKA et al. 2007) as outgroup.
MEGA version 6.06 (TAMURA et al. 2013) was used to calculate pairwise $p$-distances between the studied sequences, as well as to find the substitution model (POSADA 2003) and infer maximum likelihood (ML) tree, with 10,000 bootstrap replicates (FELSENSTEIN 1985).To test the molecular clock two hydrobiids, Peringia ulvae (Pennant, 1777) and Salenthydrobia ferreri Wilke, 2003 (AF118288, AF449214, respectively; WILKE 2003) were used as outgroups. The data of WILKE (2003), with correction of FALNIOWSKI et al. (2008) were used to calibrate the clock. The likelihood for trees with and without the molecular clock assumption for a Likelihood Ratio Test (LRT) (NEI \& KUMAR 2000, POSADA 2003) were calculated with PAUP. The Relative Rate Test (RRT) (TAJIMA 1993) was performed in MEGA. The ultrametric tree was computed with MEGA.

\section{RESULTS}

The shells of the single specimen from Khios (Fig. 4), as well as of the specimens from Rhodes (Figs 5-6) were typical of Daphniola.

The pairwise $p$-distances (Table 1) confirmed the assignment of the specimens from both Khios and Rhodes islands to Daphniola. The distance between the populations from the two islands was 0.005 , and the distances between those populations and the other Daphniola species were similar to those between the latter species. For ML analysis, the Hasegawa, Kishino \& Yano (HKY) model (NEI \& KUMAR 2000) with $\Gamma$ distribution was found. The ML tree (Fig. 7)

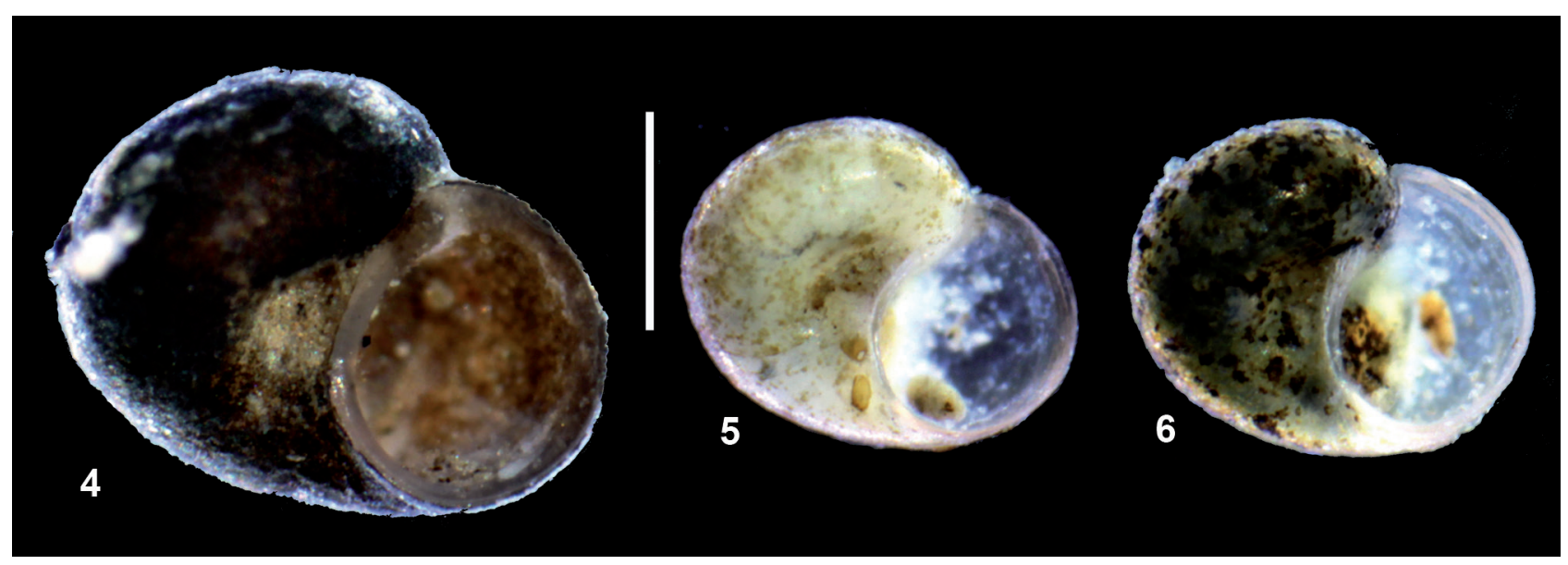

Figs 4-6. Shells of Daphniola from Aegean Islands: 4 - Khios Island, 5-6 - Rhodes Island. Bar represents 0.5 mm

Table 1. Pairwise $p$-distances between the COI sequences of Daphniola

\begin{tabular}{|c|c|c|c|c|c|c|}
\hline & 1 & 2 & 3 & 4 & 5 & 6 \\
\hline \multicolumn{7}{|l|}{ 1. \#KM887914 (9B7X Khios) } \\
\hline 2. \#KM887915 (9B9X Rhodes) & 0.005 & & & & & \\
\hline 3. \#JF916473 Daphniola hadei & 0.081 & 0.079 & & & & \\
\hline 4. \#EF070618 Daphniola louisi & 0.054 & 0.055 & 0.089 & & & \\
\hline 5. \#EU047767 Daphniola exigua & 0.092 & 0.094 & 0.082 & 0.094 & & \\
\hline 6. \#EU047763 Daphniola graeca & 0.096 & 0.097 & 0.087 & 0.096 & 0.018 & \\
\hline 7. \#EF061919 Grossuana codreanui & 0.113 & 0.111 & 0.103 & 0.111 & 0.103 & 0.108 \\
\hline
\end{tabular}




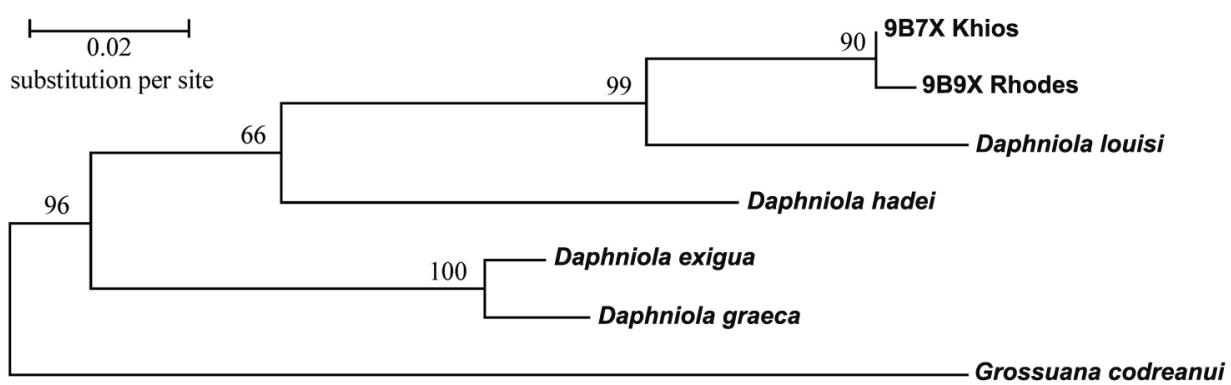

Fig. 7. Maximum likelihood tree inferred for the Daphniola COI sequences. Bootstrap supports computed with 10,000 replicates

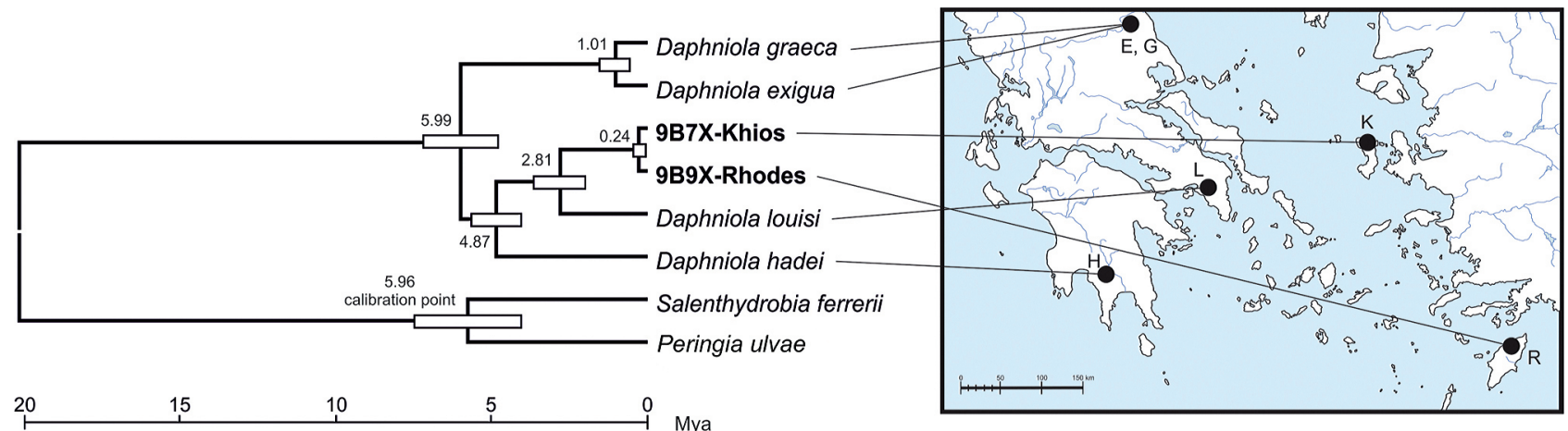

Fig. 8. Divergence time estimates for Daphniola lineages. ML ultrametric tree, time scale shown, white bars represent confidence intervals

showed D. louisi from Attica as the sister species of the one represented by the two island populations, with bootstrap support of $99 \%$.

Tajima's RRTs for each pair of Daphniola haplotypes with either Salenthydrobia or Peringia as outgroup did not reject the molecular clock hypothesis. The LRT also did not reject the molecular clock hypothesis $\left(\log L_{0}=-1911.029, \log L_{1}=-1906.901\right.$,

\section{DISCUSSION}

Both $p$-distance and the inferred ML tree indicate that the populations of Daphniola from Khios and Rhodes islands belong to the same species, despite the long distance and salt water isolation between those islands. Interestingly, the distance is more than three times smaller than between $D$. exigua and $D$. graeca living in the same valley and considered by FALNIOWSKI et al. (2007) as a single species. Perhaps either founder effect or strong selection may be an explanation. On the other hand, those populations represent a distinct species of Daphniola, at least as distinct molecularly as the three usually recognised species. Similarly high distances were found between many truncatelloidean species (SZAROWSKA et al. 2007, FALNIOWSKI et al. 2009, FALNIOWSKI \& SZAROWSKA 2011a). The sister group relationship of the island Daphniola with D. louisi from Attica is noteworthy as well.
$\Delta=8.256, \mathrm{df}=6, \mathrm{p}>0.2193)$. The two Daphniola populations from the islands and $D$. louisi split $2.81 \pm 0.86$ Mya. Divergence times for other reference species are given in Fig. 8. The split between the two main Daphniola clades occurred about $5.99 \pm 1.18$ Mya. Two other splitting events are dated for $4.87 \pm 0.85$ (Khios/Rhodes/D. lousi clade) and $1.01 \pm 0.51$ Mya (D. graeca and D. exigua).

The geographical history of Daphniola seems complex. According to our results, the splitting between the two main Daphniola clades occurred about 5.99 Mya, but with confidence intervals it is comparable with earlier estimates (FALNIOWSKI et al. 2007) and coincides with the Messinian Salinity Crisis, during which at the place of the Recent Mediterranean there was a desert with vast canyons of big rivers and with some water bodies, characterised by too low or too high salinity. Splitting time intervals occurring between the Khios/Rhodes/D. lousi clade and D. hadei from the Peloponnese could also indicate isolation of the Peloponnese populations of Daphniola at the end of the Messinian Crisis. The rapid changes in hydrographic conditions caused by the Zanclean flooding, restored the sea in the Mediterranean and thus formed barriers for freshwater fauna and changed climatic conditions. The geological and climatic events 
of this time may have promoted the diversification of Daphniola evolutionary lineages.

The next event involved splitting of $D$. exigua and D. graeca, at present found in the same valley in Thesally. This is probably a relic of recent differentiation of the Balkans' Daphniola, but more sampling is necessary for phylogeographic inferences. On the other hand, genetic distances between these two clades are of the same magnitude as those within these two populations, thus $D$. exigua and $D$. graeca are conspecific (FALNIOWSKI et al. 2007).

The low genetic divergence between $D$. louisi from Attica and the two island populations is surprising. The split between these two clades occurred about 2.8 Mya, long after the Messinian Crisis, so other events may have played a role in the divergence of these groups. It has to be noted that the present geography of the Aegean is no more than 8-6 Kya old (KougioumoutzIs et al. 2014: references therein). Since the peak of Wisconsin-Würm glaciation (24-10 Kya), global sea level has risen by 120-130 $\mathrm{m}$, and the Aegean islands replaced dry land; in the late Pleistocene the eastern Aegean islands were connected with Anatolia, and the strait between Europe

\section{REFERENCES}

Bodon M., Manganelli G., GiUsti F. 2001. A survey of the European valvatiform hydrobiid genera, with special reference to Hauffenia Pollonera, 1898 (Gastropoda: Hydrobiidae). Malacologia 43: 103-215.

FALNIOWSKI A., SzAROWSKA M. 2000. A new species of Daphniola Radoman, 1973 (Gastropoda: Hydrobiidae) from Greece. Folia Malacol. 8: 181-188. http://dx.doi. org/10.12657/folmal.008.013

FALNIOWSKI A., SZAROWSKA M., SIRBU I. 2009. Bythinella Moquin-Tandon, 1856 (Gastropoda: Rissooidea: Bythinellidae) in Romania: species richness in a glacial refugium. J. Nat. Hist. 43: 2955-2973. http://dx.doi. org/10.1080/00222930903359636

FALNIOWSKI A., SZAROWSKA M. 2011a. Genus Daphniola Radoman, 1973 (Caenogastropoda: Hydrobiidae) in the Peloponnese, Greece. Folia Malacol. 19: 131-137. http://dx.doi.org/10.2478/v10125-011-0020-9

FALNIOWSKI A., SZAROWSKA M. 2011b. A new genus and new species of valvatiform hydrobiid (Rissooidea; Caenogastropoda) from Greece. Moll. Res. 31: 189-199.

FALNIOWSKI A., SZAROWSKA M., GRZMIL P. 2007. Daphniola Radoman, 1973 (Gastropoda: Hydrobiidae): shell biometry, mtDNA, and the Pliocene flooding. J. Nat. Hist. 41: 2301-2311. http://dx.doi. org/10.1080/00222930701630733

FALNIOWSKI A., SZAROWSKA M., SirbU I., Hillebrand A., BACIU M. 2008. Heleobia dobrogica (Grossu \& Negrea, 1989) (Gastropoda: Rissooidea: Cochliopidae) and the estimated time of its isolation in a continental analogue of hydrothermal vents. Moll. Res. 28: 165-170. and the Cyclade-mega-island was rather narrow (KougioumoutZis et al. 2014).

High similarity between the Khios and Rhodes populations is unexpected, since the distance between these islands is longer than $250 \mathrm{~km}$. The most likely explanation may involve recent dispersal of Daphniola into one of these islands. Recent over-sea dispersal may be possible by stepping stones through the neighboring islands, or through the Anatolia peninsula. There are also other possible ways of colonisation, including introduction by man or by birds, which has been previously reported for other snails (e.g. GiTTENBERGER et al. 2006). There are current data indicating that small snail species may survive the passage through the digestive tract of birds (WADA et al. 2012), which makes this way of long distance colonisation a probable hypothesis.

\section{ACKNOWLEDGEMENTS}

This study was supported by a grant from the National Science Centre [2011/01/B/NZ8/00041] to ANDRZEJ FALNIOWSKI.

FELSENSTEIN J. 1985. Confidence limits on phylogenies: an approach using the bootstrap. Evolution 39: 783-791. http://dx.doi.org/10.2307/2408678

Folmer O., Black M., HoEH W., Lutz R. A., VRIJENHOEK R. C. 1994. DNA primers for amplification of mitochondrial cytochrome c oxidase subunit I from diverse metazoan invertebrates. Mol. Mar. Biol. Biotech. 3: 294-299.

GitTENBERGER E. 1982. Eine neue Horatia art aus Griecenland (Prosobranchia, Hydrobiidae). Basteria 46: 68.

GitTenberger E. D., GroenenberG S. J., KoKSHOORN B., PREECE R.C. 2006. Molecular trails from hitch-hiking snails. Nature 439: 409. http://dx.doi. org/10.1038/439409a

HALL T. A. 1999. BioEdit: a user-friendly biological sequence alignment editor and analysis program for Windows 95/98/NT. [Computer software and manual]. Nucl. Acids Symp. Ser. 41: 95-98.

Hillis D. M., MABLE B. K., LARSON A., DAVIS S. K., ZIMMER E. A. 1996. Nucleic acids IV: Sequencing and Cloning. In: Hillis D. M., Moritz C., MABle B. K. (eds). Molecular Systematics, 2 edn., Sinauer Associates Inc., Sunderland, Massachusetts, pp. 321-381.

Kougioumoutzis K., Simaiakis S. M., Tiniakou A. 2014. Network biogeographical analysis of the central Aegean archipelago. J. Biogeogr. 2014: 1-11. http://dx.doi. org/10.1111/jbi.12342

NeI M., KumAR S. 2000. Molecular evolution and phylogenetics. Oxford University Press, New York.

POSADA D. 2003. Selecting models of evolution. In: SALEMI M., VANDAMME A.-M. (eds). The phylogenetic hand- 
book. A practical approach to DNA and protein phylogeny. Cambridge University Press, Cambridge, pp. 256-282.

RADEA C. 2011. A new species of hydrobiid snails (Mollusca, Gastropoda, Hydrobiidae) from central Greece. ZooKeys 138: 53-64. http://dx.doi.org/10.3897/zookeys.138.1927

Radea C., Parmakelis A., Papadogiannis V., Charou D., TRIANTIS K. A. 2013. The hydrobioid freshwater gastropods (Caenogastropoda, Truncatelloidea) of Greece: new records, taxonomic reassessments using DNA sequence data and an update of the IUCN Red List Categories. ZooKeys 350: 1-20. http://dx.doi. org/10.3897/zookeys.350.6001

RADOMAN P. 1973. New classification of fresh and brackish water Prosobranchia from the Balkans and Asia Minor. Posebna Izdanja, Prirodnjacki Musej u Beogradu 32: $1-30$.

RADOMAN P. 1983. Hydrobioidea a superfamily of Prosobranchia (Gastropoda). I. Systematics. Serbian Academy of Sciences and Arts, Monographs 547, Department of Sciences 57: 1-256.

SCHÜTT H. 1980. Zur Kenntnis griechischer Hydrobiiden. Arch. Moll. 110: 115-149.

SZAROWSKA M., FALNIOWSKI A. 2014. Horatia Bourguignat, 1887: is this genus really phylogenetically very close to Radomaniola Szarowska, 2006 (Caenogastropoda: Truncatelloidea)? Folia Malacol. 22: 31-39. http://dx. doi.org/10.12657/folmal.022.003
SZAROWSKA M., GRZMIL P., FALNIOWSKI A., SiRbU I. 2007. Grossuana codreanui (Grossu, 1946) and the phylogenetic relationships of the East Balkan genus Grossuana (Radoman, 1973) (Gastropoda: Rissooidea). Hydrobiologia 579: 379-391. http://dx. doi.org/10.1007/s10750-006-0530-4

TAJIMA F. 1993. Simple methods for testing molecular clock hypothesis. Genetics 135: 599-607.

Tamura K., Stecher G., Peterson D. Filipski A, Kumar S. 2013. MEGA6: Molecular evolutionary genetics analysis version 6.0. Mol. Biol. Evol. 30: 2725-2729. http:// dx.doi.org/10.1093/molbev/mst197

WADA S., KAWAKAMI K., CHIBA S. 2012. Snails can survive passage through a bird's digestive system. J. Biogeogr. 39: 69-73. http://dx.doi.org/10.1111/j.13652699.2011.02559.x

WILKE T. 2003. Salenthydrobia gen. nov. (Rissooidea: Hydrobiidae): a potential relict of the Messinian sality crisis. Zool. J. Linn. Soc. London 137: 319-336. http:// dx.doi.org/10.1046/j.1096-3642.2003.00049.x

WILKE T., DAVIS G.M. 2000. Infraspecific mitochondrial sequence diversity in Hydrobia ulvae and Hydrobia ventrosa (Hydrobiidae: Rissoacea: Gastropoda): Do their different life histories affect biogeographic patterns and gene flow? Biol. J. Linn. Soc. London 70: 89-105. http://dx. doi.org/10.1111/j.1095-8312.2000.tb00202.x

Received: June 1st, 2014

Revised: July 31st/September 8th, 2014

Accepted: September 9th, 2014

Published on-line: November 19th, 2014 